\title{
Correlation of tissue, blood, and air partition coefficients of volatile organic chemicals
}

\author{
SALLY PATERSON, D MACKAY \\ From the Institute for Environmental Studies, University of Toronto, Toronto, Ontario, Canada M5S 1 A4
}

\begin{abstract}
The physical chemical factors controlling partition coefficients between air, water, blood, and various tissues are discussed. It is suggested that improved insights into the relations between partition coefficients, which are frequently expressed as correlations, may be obtained by viewing the partition coefficients as ratios of solubilities or pseudosolubilities. A simple, novel correlation approach is developed and applied to 24 volatile organic chemicals, which enables tissue/blood, tissue/air, and blood/air partition coefficients to be estimated from water solubility and vapour pressure. An illustration is presented in which these solubilities are used to calculate the equilibrium distribution of dichloromethane between air, blood, and various tissues.
\end{abstract}

Pharmacokinetic models have proved useful in predicting the concentration time course of drugs, anaesthetics, industrial solvents, and environmental contaminants in blood and biological tissue. They have been applied to the design of optimum drug or anaesthetic regimens, determination of the kinetics of industrial toxicants, and the relation between environmental levels of chemicals and their concentrations in human or animal tissue. They permit prediction of the physiological distribution of chemicals of similar properties, extrapolation of this distribution to other species, and aid in the interpretation of responses.

In these models it is essential to include reliable expressions for tissue/blood and blood/gas partitioning, as well as for physiological volume and kinetic parameters. Thus there is an incentive to develop methods to correlate and predict tissue/gas and blood/ gas partition coefficients. Several studies have reported such correlations. ${ }^{1-4}$

In the present paper we discuss and illustrate a novel approach for calculating and correlating partitioning characteristics. Rather than correlate partition coefficients, which are inherently functions of properties of the chemical in two phases-for example, tissue and blood or tissue and air-we treat each phase individually and assign and correlate a single "solubility" property to each chemical in each phase. The advantage of this approach is that it shows immediately how a partition coefficient is influenced by each contributing phase. Most important, it avoids

Accepted 23 May 1988 a problem of developing apparently significant correlations by inadvertently correlating a quantity with itself. It also leads to a simple method of calculating equilibrium concentrations and distributions of chemicals within an organism.

To illustrate the statistical problem, we consider a series of chemicals (subscripts $1,2,3$ ) of limited solubility in water, fat, and a tissue (subscripts W, F, and $T$ ). The partition coefficients-for instance, $K_{\mathrm{Fwl}}$, the partition coefficient of chemical 1 between fat and water-may also be regarded as the ratio of the solubility $S_{\mathrm{F} 1}$ and $S_{\mathrm{W}_{1}}$-that is, $\mathrm{K}_{\mathrm{FW} 1}$ is $\mathrm{S}_{\mathrm{Fl}} / \mathrm{S}_{\mathrm{W}_{1}}$. For example, a set of solubility data in arbitrary units may be:

$$
\begin{array}{lll}
S_{\mathrm{F} 1}=1000 & \mathrm{~S}_{\mathrm{T} 1}=300 & \mathrm{~S}_{\mathrm{W} 1}=100 \\
\mathrm{~S}_{\mathrm{F} 2}=900 & \mathrm{~S}_{\mathrm{T} 2}=250 & \mathrm{~S}_{\mathrm{W} 2}=10 \\
\mathrm{~S}_{\mathrm{F} 3}=800 & \mathrm{~S}_{\mathrm{T} 3}=280 & \mathrm{~S}_{\mathrm{W} 3}=1
\end{array}
$$

The corresponding partition coefficients are thus:

$$
\begin{aligned}
& \mathrm{K}_{\mathrm{FW}_{1}}=10 \mathrm{~K}_{\mathrm{TW} 1}=3\left(\mathrm{~S}_{\mathrm{T} 1} / \mathrm{S}_{\mathrm{w}_{1}}\right) \\
& \mathrm{K}_{\mathrm{FW} 2}=90 \mathrm{~K}_{\mathrm{TW} 2}=25 \\
& \mathrm{~K}_{\mathrm{FW}_{3}}=800 \mathrm{~K}_{\mathrm{TW} 3}=280
\end{aligned}
$$

Regression of $\mathrm{K}_{\mathrm{FW}}$ with $\mathrm{K}_{\mathrm{Tw}}$ will show an apparently significant relation with $\mathrm{K}_{\mathrm{Fw}}$ approximately equal to $3.2 \mathrm{~K}_{\mathrm{Tw}}$. This correlation, however, is entirely the result of the presence of $S_{w}$ in the denominator of both quantities. This water solubility varies by a factor of 100 whereas the fat and tissue solubilities are fairly constant and do not contribute significantly to the variation in partition coefficient between chemicals. This constancy is obscured when only partition coefficients are used since it is not immediately clear 
which phase(s) contribute to the variation in the $K$ values. The linear partition coefficient regressions may thus be distorted by containing three variables. Accordingly, we suggest that more insight into relations between partition coefficients may be gained by viewing each phase individually.

By this approach it is possible to deduce probable partition coefficients from water solubility alonethat is, where no partition coefficient data exist. For example, if a fourth structurally similar chemical in this series has a water solubility of 50 , it may be estimated that its fat/water and tissue/water partition coefficients will be about 20 and 6 respectively.

\section{Phase equilibria}

We first set out the rigorous thermodynamic basis of phase equilibrium using fugacity as an equilibrium criterion, derive relations between fugacities, solubilities, and partition coefficients, and then illustrate the approach for a set of relatively volatile organic chemicals that are of pharmacokinetic interest. The thermodynamic background is reviewed by Prausnitz.

When characterising the partitioning of an organic chemical between two phases such as water and fat, a partition coefficient $\mathrm{K}_{\mathrm{ij}}$ is usually defined as the dimensionless concentration ratio $C_{i} / C_{j}$ where $C$ may have units such as $\mathrm{g} / \mathrm{l}, \mathrm{mol} / \mathrm{l}$ or $\mathrm{mol} / \mathrm{m}^{3}$. At equilibrium, the chemical potentials, activities, or fugacities of the solute are equal in each phase. An alternative method of expressing partitioning is to relate each concentration separately to a common chemical potential, activity, or fugacity. This latter approach has the advantage that it clearly divides the partition coefficient into the two separate contributions of each phase. It is particularly advantageous to use fugacity as the equilibrium criterion since it is approximately linearly related to concentration, whereas chemical potential is logarithmically related. To elucidate the relations between partition coefficients we discuss their fundamental relations to fugacity.

We adopt the approach here of defining for each chemical in each phase a solubility or "pseudosolubility" such that the partition coefficient between these two phases is the ratio of these solubilities.

For a gas phase, or air, the fugacity $\mathrm{f} P$ of a solvent is essentially equal to its partial pressure $\mathrm{P} \mathrm{Pa}$, the exceptions occurring when the solvent self-associates as in the case of $\mathrm{NO}_{2}$ or carboxylic acids. The partial pressure is related to concentration in air $\mathrm{C}_{\mathrm{A}} \mathrm{mol} / \mathrm{m}^{3}$ through the gas law as

$$
C_{A}=P / R T=f / R T
$$

where $R$ is the gas constant $8.314 \mathrm{~Pa} \mathrm{~m}^{3} / \mathrm{mol} \mathrm{K}$ and $T$ is absolute temperature $K$. The maximum or saturation solubility in air $\mathrm{C}_{\mathrm{A}}{ }^{\mathrm{s}}$ occurs when $\mathrm{P}$ equals the vapou pressure $P^{s}$, and $C_{A}^{s}$ equals $P^{s} / R T$. Solubilities in a禺 may thus be determined readily from vapour pressure data.

For a liquid phase such as water the fugacity expressed as

$$
\mathbf{f}=\mathbf{x} \gamma \mathbf{P}^{s}
$$

where $\mathbf{x}$ is the mole fraction of solvent, $\gamma$ is an activity coefficient or correction factor for non-ideality, and $\mathrm{Ps}^{\mathrm{s}}$ is the vapour pressure of the pure liquid chemical al the system temperature. This is essentially a statement of Raoult's Law, corrected if necessary with the factor $\gamma$. Now $\mathrm{x}$ is related to concentration by

$$
\mathrm{C}_{\mathrm{L}}=\mathrm{x} / \mathrm{v}
$$

where $\mathrm{v}$ is the molar volume of the liquid solvent $\left(\mathrm{m}^{3} / \mathrm{mol}\right)$ and is, for example, $18 \times 10^{-6} \mathrm{~m}^{3} / \mathrm{mol}$ of $18 \mathrm{~cm}^{3} / \mathrm{mol}$ for water. Inherent in this equation is the assumption that the solute is present at a low enough concentration that it does not substantially affect the molar volume. From equations 2 and 3 it follows the the concentration is given by

$$
\mathrm{C}_{\mathrm{L}}=\mathrm{f} /\left(\mathbf{v} \gamma \mathrm{P}^{\mathrm{s}}\right)
$$

Now, at saturation conditions, the chemical's fugacity and vapour pressure are usually equal, thus the solubility of the chemical in the liquid is given by

$$
\mathrm{C}_{\mathrm{L}}{ }^{\mathrm{s}}=1 / \mathrm{v} \gamma
$$

There are three methods of estimating $\mathrm{C}_{\mathrm{L}} \mathrm{s}$.

Firstly, for sparingly soluble liquids such as benzen in water the solubility may be measured directly. For example, benzene has a solubility in water of $1780 \mathrm{~g} / \mathrm{m}$ or $22.8 \mathrm{~mol} / \mathrm{m}^{3}$, thus $\gamma$ is 2440 indicating a high degree of non-ideality in the water phase - that is, the benzene exerts a partial pressure 2440 times that suggested by Raoult's Law.

Secondly, information or correlations may available on the magnitude of $\gamma$ from vapour/liqua equilibrium or other measurements as reviewed, for instance, by Reid et al. ${ }^{6}$ For example, correlations are available for infinite dilution activity coefficients alcohols in water. ${ }^{6}$ Thus for an alcohol of activit: coefficient $\gamma$ equal to 3 in water of molar volume 18 go $10^{-6} \mathrm{~mol} / \mathrm{m}^{3}$, the solubility $\mathrm{C}_{\mathrm{L}}{ }^{\mathrm{s}}$ is $18500 \mathrm{~mol} / \mathrm{m}^{3}$. If reality, the alcohol is miscible with water and solubility may be determined experimentally. $C_{L}{ }^{5} \phi$ thus a pseudosolubility which may only be calculate not measured directly.

The third method uses air/liquid partition data 兽 the form of gas solubilities or Henry's law constants. For complex liquids there is often doubt about $\gamma$ and 7 and it may be convenient to combine them and $P^{s}$ in single quantity $\mathrm{H}$ the Henry's law constant $\mathrm{H} \mathrm{Pa}$ m mol expressed as 
Thus

$$
\mathrm{H}=\mathrm{P} / \mathrm{C}=\mathrm{f} / \mathrm{C}=\mathrm{v} \gamma \mathrm{P}^{\mathrm{s}}
$$

$$
\mathrm{C}=\mathrm{f} / \mathrm{H}
$$

If we assume that $\mathrm{H}$ is not only $\mathrm{P} / \mathrm{C}$ but also $\mathrm{P}^{\mathrm{s}} / \mathrm{C}^{\mathrm{s}}$ the ratio of the saturation vapour pressure to the solubility in the liquid $\mathrm{C}_{\mathrm{L}}{ }^{\mathrm{s}} \mathrm{mol} / \mathrm{m}^{3}$, then

$$
\mathrm{C}_{\mathrm{L}}^{\mathrm{s}}=\mathrm{P}^{\mathrm{s}} / \mathrm{H}
$$

For this method a vapour pressure and a Henry's law constant are required. The latter may be in the form of a gas/liquid or gas/tissue partition coefficient (equivalent to $H / R T$ ) or an Ostwald or Bunsen gas solubility coefficient.

Complex liquids or solid/liquid mixtures are conveniently treated as additive volumes of different components. For example, blood may be treated as a mixture of water, lipid, protein, and other components. If each component is assigned separate properties and an effective volume fraction y the bulk properties of the mixture, such as $C^{s}$, may be expressed as the sum of that of the components,

$$
\mathrm{C}^{s}=\mathrm{y}_{1} \mathrm{C}_{1}^{s_{1}}+\mathrm{y}_{2} \mathrm{C}_{2}^{\mathrm{s}}+\mathrm{etc}=\Sigma \mathrm{y}_{\mathrm{i}} \mathrm{C}_{\mathrm{i}}^{\mathrm{s}}
$$

Having established these individual solubility relations, the various partition coefficients may be deduced as follows

$$
\begin{array}{r}
\text { Liquid/air-for example, water/air or oil/air } \\
\mathrm{K}=\mathrm{C}_{\mathrm{L}} / \mathrm{C}_{\mathrm{A}}=\left(\mathrm{f} /\left(\mathbf{v} \gamma \mathrm{P}^{\mathrm{s}}\right) /(\mathrm{f} / \mathrm{RT})\right) \\
=\mathrm{RT} / \mathrm{v} \gamma \mathrm{P}^{\mathrm{s}}=\mathrm{C}_{2}^{\mathrm{s}} \mathrm{RT} / \mathrm{P}^{\mathrm{s}}
\end{array}
$$

$\mathrm{K}$ may be regarded as the ratio of solubility in the liquid $C_{L}^{s}$ to solubility in air $C_{A}^{s}$ or $P^{s} / R T$.

Liquid/liquid-for example, oil/water

$$
\mathbf{K}=\mathbf{C}_{\mathbf{L} 1}^{\mathbf{s}} / \mathbf{C}_{\mathbf{L} 2}^{\mathrm{s}}=\mathbf{v}_{2} \gamma_{2} / \mathbf{v}_{1} \gamma_{1}
$$

Clearly the reason that a solute such as benzene has such a high oil/water partition coefficient is that it has a low solubility in water $C_{\mathrm{L} 2}^{\mathrm{s}}$ due to its large activity coefficient $\gamma_{2}$ in water. Its solubility in oil $\mathbf{C}_{\mathrm{L} 1}^{\mathrm{s}}$ is relatively large and $\gamma_{1}$, relatively small (say, 3 ) reflecting the near ideality of the mixture of organic solvent in an organic medium.

$$
\begin{array}{r}
\text { Complex liquid/air-for example, blood/air } \\
\mathrm{K}=\mathrm{C}_{\mathrm{c}} / \mathrm{C}_{\mathrm{A}}=\Sigma\left[\mathrm{y}_{\mathrm{i}} \mathrm{C}_{\mathrm{Li}}^{\mathrm{s}}\right] / \mathrm{C}_{\mathrm{A}}=\left(\mathrm{RT} / \mathrm{P}^{\mathrm{s}}\right) \Sigma\left[\mathrm{y}_{\mathrm{i}} \mathrm{C}_{\mathrm{Li}}^{\mathrm{s}}\right] \\
=\Sigma\left[\mathrm{y}_{\mathrm{i}}\left(\mathrm{C}_{\mathrm{Li}}^{\mathrm{s}} \mathbf{R T} / \mathrm{P}^{\mathrm{s}}\right)\right]=\Sigma\left[\mathrm{y}_{\mathrm{i}} \mathrm{K}_{\mathrm{iA}}\right]
\end{array}
$$

where $\mathrm{K}_{\mathrm{iA}}$ is the component/air partition coefficient.

Complex liquid/liquid-for example, blood/fat

$$
\begin{aligned}
\mathbf{K}=\mathrm{C}_{\mathrm{c}} / \mathrm{C}_{\mathrm{L}}=\Sigma \mathrm{y}_{\mathrm{i}} \mathrm{C}_{\mathrm{Li}}^{\mathrm{s}} / \mathrm{C}_{\mathrm{L}}^{\mathrm{s}}=\mathrm{v}_{\mathrm{L}} \gamma_{\mathrm{L}} \Sigma\left[\mathrm{y}_{\mathrm{i}} \mathrm{C}_{\mathrm{Li}}^{\mathrm{s}}\right] & \\
& =\Sigma\left[\mathrm{y}_{\mathrm{i}}\left(\gamma_{\mathrm{L}} \mathbf{v}_{\mathrm{L}} / \gamma_{\mathrm{i}} \mathbf{v}_{\mathrm{i}}\right)\right]=\Sigma\left[\mathbf{y}_{\mathrm{i}} \mathbf{K}_{\mathrm{iL}}\right]
\end{aligned}
$$

For a complex liquid the bulk partition coefficients are thus expected to be additive in proportion to the volume fractions of the contributing phases.

When correlating partition coefficients we suggest that it is preferable to examine the individual phase solubilities or pseudosolubilities rather than their ratios because, as was discussed earlier, two variables $x$ and $y$ which are unrelated may appear to be related if plotted as $x / z$ versus $y / z$. Fat/air and muscle/air partition coefficients appear to be related because both contain the air solubility. It is preferable to examine a chemical's fat solubility and muscle solubility separately and independently of their common air solubility.

A common surrogate for organic phases is $n$ octanol and extensive data exist for $\mathbf{n}$-octanol-water partition coefficients $\mathrm{K}_{\mathrm{ow}}$ of solvents. ${ }^{7}$ Recently Miller et al have shown that this partition coefficient is primarily controlled by water solubility, with a contribution from solute molar volume. ${ }^{8}$ It is thus possible to estimate $\mathbf{K}_{\text {ow }}$ from aqueous solubility. If a water solubility or pseudosolubility is available a solubility or pseudosolubility in octanol may be estimated as $\mathrm{K}_{\mathrm{ow}} \mathrm{C}_{\mathrm{L}}^{\mathrm{s}}$, by assuming that $\mathrm{K}_{\mathrm{ow}}$ is not only the ratio of concentrations but also the ratio of solubilities. Other less defined organic liquids such as olive oil may also be used for this purpose.

In summary, equations have been presented expressing fugacity, solubility, and partition coefficients in terms of the fundamental thermodynamic quantities $\gamma$, $\mathrm{P}^{\mathbf{s}}, \mathrm{C}^{\mathbf{s}}$, and molar volumes $\mathrm{v}$ for simple phases with $\mathrm{a}$ further dependence on volume fractions y for complex phases. We now examine the partition coefficients reported in publications and deduce the values of the fundamental phase solubilities, hoping that these solubilities may be individually predictable. Subsequently, we illustrate how these solubilities may be used to predict equilibrium concentrations.

\section{Data analysis}

Table 1 gives the physical chemical properties of 24 volatile organic chemicals including the actual or pseudosolubilities in water, the saturation concentration or solubility in air $\left(\mathrm{P}^{\mathrm{s}} / \mathrm{RT}\right)$, and the pseudosolubility in octanol $\mathrm{K}_{\mathrm{ow}} \mathrm{C}^{\mathrm{s}}$. The water solubilities have been obtained either from data ${ }^{8101113}$ or calculated from activity coefficients ${ }^{9}$ or Oswald coefficients ${ }^{15}$ as described earlier.

Table 2 gives values of selected tissue/air and blood/ air partition coefficients for these chemicals..$^{1-316}$ By combining the partition coefficients and the air solubilities, solubilities in blood and various tissues may be calculated for each compound (table 3).

\section{Results and discussion}

It is striking that the water solubilities in table 1 range from 0.006 to $27000 \mathrm{~mol} / \mathrm{m}^{3}$, a factor of 4.5 million. The air solubilities vary from 0.7 to 42 , a factor of only 60 . The octanol solubilities vary from 700 to 6000 , 
Table 1 Physical chemical properties of 24 volatile organic chemicals at $37^{\circ} \mathrm{C}$ except for alkane solubilities which are at $25^{\circ} C_{9^{-14}}$ The solubilities were obtained as indicated in the last column from data $(E),{ }^{810 ~} 1113$ activity coefficient correlations $(A), ?$ or from Ostwald coefficients $(O)^{15}$

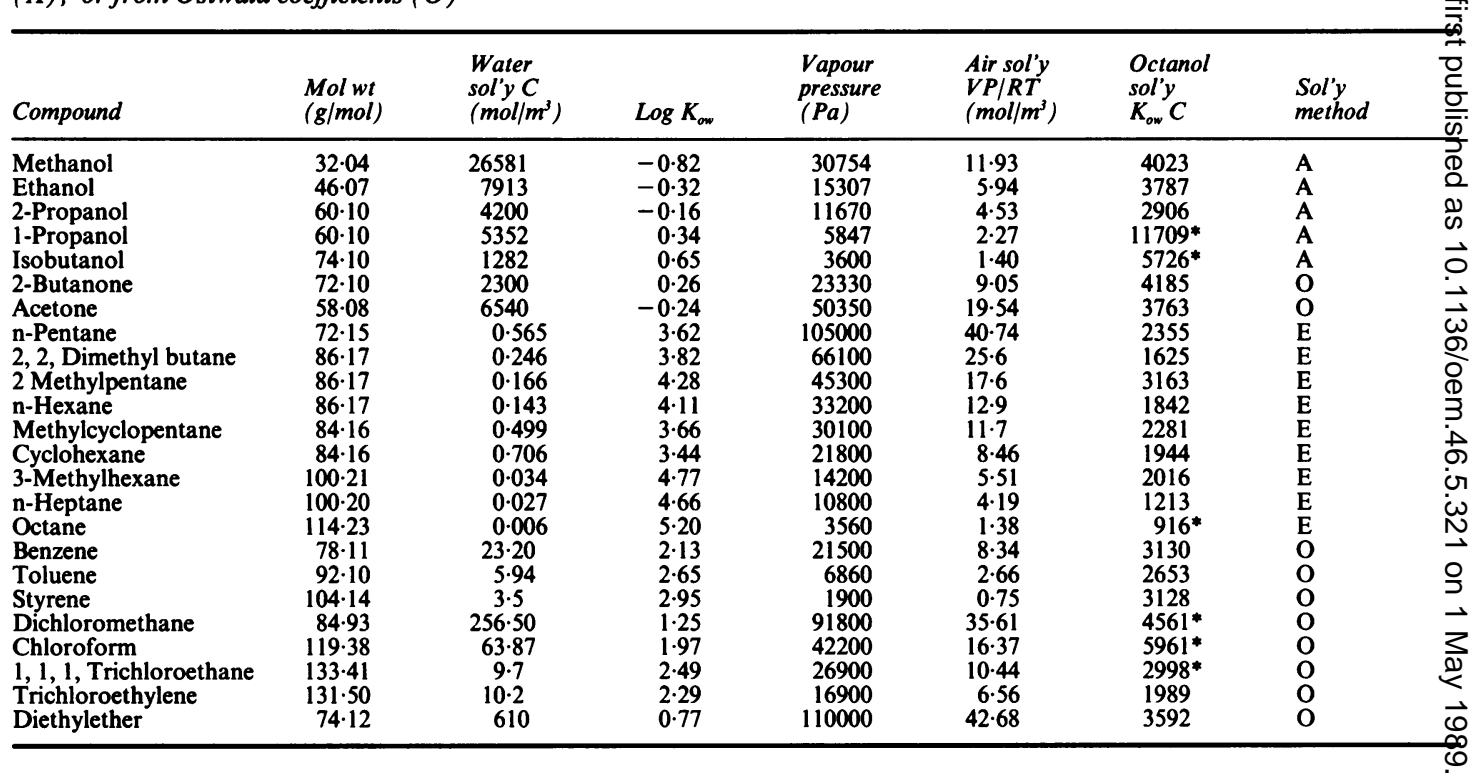

only a factor of $\mathbf{8 . 6}$. It is suspected that the octanol solubilities are more constant than is indicated. If six suspect values (indicated by asterisks) are removed, the mean solubility in octanol is $2750 \mathrm{~mol} / \mathrm{m}^{3}$ with $75 \%$ of the chemicals lying in the range 2000 $4000 \mathrm{~mol} / \mathrm{m}^{3}$.

To a first approximation, the octanol solubilities may be considered constant, especially when considered by comparison with the water and air solubilities. The oil and fat solubilities in table 3 are fairly constant with mean values of 3000 and $2000 \mathrm{~mol} / \mathrm{m}^{3}$ respectively. They are thus similar to the solubilities in octanol. The solubility in fat may be considered to be about $73 \%$ of the solubility octanol. The mean solubility in oil which is slight larger than that in octanol in this case will vary wit the type of oil used. Octanol and oil are thus good surrogates for fat when attempting to predie

Table 2 Reported tissue/gas partition coefficients for the 24 chemicals $^{1-3} 16$

\begin{tabular}{|c|c|c|c|c|c|c|c|c|c|c|}
\hline & Oil & Blood & Liver & Kidney & Brain & Fat & Muscle & Heart & Lung & \\
\hline $\begin{array}{l}\text { Methanol } \\
\text { Ethanol } \\
\text { 2-Propanol } \\
\text { 1-Propanol } \\
\text { Isobutanol } \\
\text { 2-Butanone } \\
\text { Acetone } \\
\text { n-Pentane } \\
\text { 2, 2, Dimethyl butane } \\
\text { 2 Methylpentane } \\
\text { n-Hexane } \\
\text { Methylcyclopentane } \\
\text { Cyclohexane } \\
\text { 3-Methylhexane } \\
\text { n-Heptane } \\
\text { Octane } \\
\text { Benzene } \\
\text { Toluene } \\
\text { Styrene } \\
\text { Dichloromethane } \\
\text { Chloroform } \\
\text { 1, 1, 1, Trichloroethane } \\
\text { Trichloroethylene } \\
\text { Diethylether }\end{array}$ & $\begin{array}{r}86 \\
47 \\
71 \\
103 \\
146 \\
202 \\
293 \\
311 \\
452 \\
492 \\
1471 \\
\\
152 \\
401 \\
356 \\
718 \\
65\end{array}$ & $\begin{array}{c}2874 \\
2516 \\
1426 \\
955 \\
896 \\
215 \\
330 \\
0 \cdot 38 \\
0 \cdot 26 \\
0 \cdot 41 \\
0 \cdot 80 \\
0 \cdot 86 \\
1 \cdot 3 \\
1 \cdot 3 \\
1.9 \\
7 \cdot 8 \\
15 \cdot 6 \\
52 \\
9 \cdot 7 \\
10 \cdot 30 \\
38 \cdot 60 \\
9 \cdot 50 \\
12.00\end{array}$ & $\begin{array}{r}2 \cdot 1 \\
3 \cdot 5 \\
4 \cdot 5 \\
5 \cdot 2 \\
7 \cdot 8 \\
10 \cdot 8 \\
10 \cdot 6 \\
10 \cdot 8 \\
26 \\
23 \\
48 \\
140 \\
7 \cdot 2 \\
17 \\
17 \\
29 \\
11\end{array}$ & $\begin{array}{l}1355 \\
940 \\
503 \\
686 \\
371 \\
107 \\
146 \\
0 \cdot 6 \\
1 \cdot 4 \\
2 \cdot 0 \\
3 \cdot 0 \\
4 \cdot 7 \\
7 \cdot 2 \\
7 \cdot 3 \\
8 \cdot 9 \\
8 \cdot 2 \\
12 \\
18 \\
\\
5 \cdot 8 \\
11 \\
6 \cdot 7 \\
15 \\
10\end{array}$ & $\begin{array}{r}1413 \\
1044 \\
560 \\
720 \\
387 \\
111 \\
148 \\
2 \cdot 2 \\
2 \cdot 8 \\
3 \cdot 8 \\
5 \cdot 0 \\
7 \cdot 3 \\
10 \cdot 7 \\
10 \cdot 2 \\
12 \cdot 4 \\
16 \cdot 5 \\
18 \\
36 \\
\\
6 \cdot 0 \\
20 \\
8 \cdot 3 \\
21 \\
12\end{array}$ & $\begin{array}{r}231 \\
215 \\
180 \\
296 \\
388 \\
162 \\
86 \\
39 \cdot 6 \\
66 \\
87 \\
104 \\
176 \\
260 \\
277 \\
385 \\
233 \\
425 \\
962 \\
2600 \\
85 \\
280 \\
251 \\
569 \\
50\end{array}$ & $\begin{array}{r}1309 \\
850 \\
502 \\
678 \\
343 \\
103 \\
151 \\
0 \cdot 7 \\
1.0 \\
2.9 \\
5.0 \\
5.0 \\
10 \cdot 5 \\
10 \cdot 8 \\
12.5 \\
8.6 \\
16 \\
35 \\
52 \\
4.8 \\
12 \\
6 \cdot 7 \\
19 \\
10\end{array}$ & $\begin{array}{c}0 \cdot 2 \\
0 \cdot 5 \\
1 \cdot 4 \\
2 \cdot 8 \\
1.9 \\
5 \cdot 8 \\
5 \cdot 3 \\
6 \cdot 1 \\
18 \\
17 \\
30 \\
7 \cdot 0 \\
8 \\
9 \cdot 0 \\
20 \\
12\end{array}$ & $\begin{array}{c}1733 \\
1172 \\
590 \\
817 \\
400 \\
103 \\
160 \\
0.5 \\
0.6 \\
0.8 \\
1.0 \\
1.7 \\
2.7 \\
2.5 \\
5.0 \\
12 \\
21 \\
\\
5.8 \\
7 \\
4.7 \\
14 \\
15\end{array}$ & 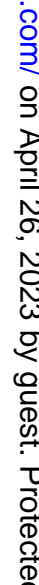 \\
\hline
\end{tabular}


Table 3 Calculated solubilities or pseudosolubilities $\left(\mathrm{mol} / \mathrm{m}^{3}\right)$ of the chemicals in various tissue groups using data in tables 1 and 2

\begin{tabular}{|c|c|c|c|c|c|c|c|c|c|}
\hline & Oil & Blood & Liver & Kidney & Brain & Fat & Muscle & Heart & Lung \\
\hline $\begin{array}{l}\text { Methanol } \\
\text { Ethanol } \\
\text { 2-Propanol } \\
\text { 1-Propanol } \\
\text { Isobutanol } \\
\text { 2-Butanone } \\
\text { Acetone } \\
\text { n-Pentane } \\
\text { 2, 2, Dimethyl butane } \\
\text { 2 Methylpentane } \\
\text { n-Hexane } \\
\text { Methylcyclopentane } \\
\text { Cyclohexane } \\
\text { 3-Methylhexane } \\
\text { n-Heptane } \\
\text { Octane } \\
\text { Benzene } \\
\text { Toluene } \\
\text { Styrene } \\
\text { Dichloromethane } \\
\text { Chloroform } \\
\text { 1, 1, 1, Trichloroethane } \\
\text { Trichloroethylene } \\
\text { Diethylether }\end{array}$ & $\begin{array}{l}1680 \\
1915 \\
1821 \\
1810 \\
1881 \\
2359 \\
2478 \\
1713 \\
1894 \\
\\
4104 \\
3915 \\
5412 \\
6566 \\
3716 \\
4708 \\
2774\end{array}$ & $\begin{array}{c}34294 \\
14943 \\
6457 \\
2167 \\
1252 \\
1946 \\
6447 \\
15 \cdot 5 \\
6 \cdot 7 \\
7 \cdot 2 \\
10 \cdot 3 \\
10 \cdot 0 \\
11 \cdot 0 \\
7 \cdot 2 \\
8 \cdot 0 \\
9 \cdot 48 \\
65 \cdot 1 \\
41 \cdot 5 \\
38 \cdot 9 \\
345 \cdot 4 \\
168 \cdot 6 \\
402 \cdot 9 \\
62 \cdot 3 \\
512 \cdot 2\end{array}$ & $\begin{array}{r}85.6 \\
89.8 \\
79 \cdot 1 \\
67 \cdot 0 \\
91 \cdot 1 \\
91 \cdot 4 \\
58 \cdot 4 \\
45 \cdot 3 \\
35 \cdot 9 \\
191 \cdot 9 \\
127 \cdot 8 \\
104 \cdot 8 \\
256 \cdot 4 \\
278 \cdot 4 \\
177 \cdot 4 \\
190 \cdot 2 \\
469 \cdot 5\end{array}$ & $\begin{array}{r}16169 \\
5583 \\
2278 \\
1556 \\
518 \\
969 \\
2852 \\
24 \cdot 4 \\
35 \cdot 9 \\
35 \cdot 2 \\
38 \cdot 6 \\
54 \cdot 9 \\
60 \cdot 9 \\
40 \cdot 2 \\
37 \cdot 3 \\
11 \cdot 3 \\
100 \cdot 1 \\
47 \cdot 9 \\
206 \cdot 5 \\
180 \cdot 1 \\
69 \cdot 9 \\
98 \cdot 4 \\
426 \cdot 8\end{array}$ & $\begin{array}{r}16861 \\
6200 \\
2536 \\
1633 \\
541 \\
1005 \\
2891 \\
89 \cdot 6 \\
71 \cdot 8 \\
66 \cdot 8 \\
64 \cdot 4 \\
85 \cdot 3 \\
90 \cdot 5 \\
56 \cdot 2 \\
52 \cdot 0 \\
22 \cdot 8 \\
150 \cdot 2 \\
95 \cdot 8 \\
\\
213 \cdot 6 \\
327 \cdot 5 \\
137 \cdot 7 \\
512 \cdot 2\end{array}$ & $\begin{array}{r}2756 \\
1277 \\
815 \\
672 \\
542 \\
1466 \\
1680 \\
1613 \\
1693 \\
1529 \\
1340 \\
2055 \\
2199 \\
1526 \\
1613 \\
322 \\
3545 \\
2561 \\
1947 \\
3027 \\
4585 \\
2620 \\
3731 \\
2134\end{array}$ & $\begin{array}{r}15620 \\
5048 \\
2273 \\
1538 \\
479 \\
932 \\
2950 \\
28.5 \\
25.6 \\
51.0 \\
64.4 \\
58.4 \\
88.8 \\
59.5 \\
52.4 \\
11.9 \\
133.5 \\
93.2 \\
38.9 \\
170.9 \\
196.5 \\
69.9 \\
124.6 \\
426.8\end{array}$ & $\begin{array}{c}8 \cdot 15 \\
12.8 \\
24.6 \\
36 \cdot 1 \\
22.2 \\
49 \cdot 1 \\
29.2 \\
25.6 \\
24.9 \\
141 \cdot 8 \\
79.9 \\
249.2 \\
131.0 \\
93.9 \\
131 \cdot 1 \\
512.2\end{array}$ & $\begin{array}{r}20679 \\
6961 \\
2672 \\
1853 \\
559 \\
932 \\
3126 \\
20 \cdot 4 \\
15 \cdot 4 \\
14 \cdot 1 \\
12.9 \\
19.9 \\
22 \cdot 8 \\
10 \cdot 5 \\
6.9 \\
100 \cdot 1 \\
55.9 \\
\\
206.5 \\
114.6 \\
49.1 \\
91 \cdot 8 \\
640 \cdot 2\end{array}$ \\
\hline
\end{tabular}

solubilities or partition coefficients.

Blood solubilities in table 3 range from 7 to 34000 with two striking features. For water miscible chemicals such as the alcohols, the solubility in blood approximates that in water $\mathrm{C}_{\mathrm{w}}^{\mathrm{s}}$ indicating that there is a negligible contribution to solubility by partitioning into blood lipids. For sparingly soluble compounds such as the alkanes, the solubility in blood is between 0.3 and $1 \%$ of the alkane's solubility in fat, and greatly exceeds the solubility in water, indicating that partitioning of these chemicals in blood is mainly into a lipid-like phase. For these sparingly water soluble chemicals in table 3 , the average blood solubility is $9.5 \mathrm{~mol} / \mathrm{m}^{3}$. Thus the blood solubility $S_{B}$ may be estimated from the water and octanol solubilities as

or

$$
S_{B}=C_{W}^{s}+9.5
$$

$$
\mathrm{S}_{\mathrm{B}}=\mathrm{C}_{\mathrm{w}}^{\mathrm{s}}+0.0035 \mathrm{~S}_{0}
$$

where $S_{B}, S_{F}$, and $S_{0}$ represent solubility in blood, fat, and octanol respectively with units of $\mathrm{mol} / \mathrm{m}^{3}$. If an octanol/water partition coefficient $\mathrm{K}_{\mathrm{ow}}$ is available the blood solubility could also be estimated from

since $\mathrm{S}_{0}$ is $\mathrm{C}_{\mathrm{w}}^{\mathrm{s}} \mathrm{K}_{\text {ow }}$.

$$
S_{B}=C_{W}^{s}\left(1+0.0035 K_{\text {ow }}\right)
$$

Examination of the tissue group solubilities shows that they have characteristics of solubility in both water and fat with the water solubility controlling again for the alcohols and the fat solubility for the alkanes. There are some suspect values which we believe may be due to errors in published values of partition coefficients and physical chemical properties.
For each chemical a solubility in a tissue, $S_{\mathrm{T}}$, may be calculated as

$$
\mathrm{S}_{\mathrm{T}}=\mathrm{xS}_{0}+\mathrm{yC}_{\mathrm{w}}^{\mathrm{s}}
$$

The constant $x$ may be calculated using average tissue solubility data for those chemicals of low water solubility. An average value of y may be obtained by substituting the above $\mathrm{x}$ in the above equation for the highly water soluble chemicals. Alternatively, linear regression may be used. This method was applied to obtain correlations for solubilities in kidney, liver, and brain.

It is interesting that when using this approach the aromatics display solubilities in blood that are consistently higher than those predicted. For example, for benzene, published blood solubilities $\left(\mathrm{mol} / \mathrm{m}^{3}\right)$ are 65 compared with the predicted 34 ; for toluene, 41 against 16; and for styrene 39 against 14 . This suggests an additional protein or other binding corresponding to a solubility increase of $30 \mathrm{~mol} / \mathrm{m}^{3}$ for these aromatics. The reported solubilities of benzene and toluene in kidney, liver, and fat are also larger than those predicted but not by such a constant amount as in the case of blood. This again could be due to protein binding.

In summary, the following correlation system is suggested.

From the reported vapour pressure $\mathrm{P}^{s}(\mathrm{~Pa})$ the air solubility $\left(\mathrm{P}^{\mathrm{s}} / \mathrm{RT}\right)$ or $\mathrm{C}_{\mathrm{A}}^{\mathbf{s}}$ is calculated. From the actual water solubility, or an activity coefficient correlation, or a gas/water partition coefficient, a water solubility $\mathrm{C}_{\mathrm{w}}^{\mathrm{s}}$ is calculated. 
The other assumed solubilities $\left(\mathrm{mol} / \mathrm{m}^{3}\right)$ are:

$$
\begin{array}{ll}
\text { Octanol } & \mathrm{S}_{0}=2750 \\
\text { Oil } & \mathrm{S}_{\text {oil }}=3000 \\
\text { Fat } & \mathrm{S}_{\mathrm{F}}=2000
\end{array}
$$

The tissue solubilities may then be calculated as follows:

$$
\begin{aligned}
& \text { Kidney } \\
& S_{K}=0.014 S_{0}+0.51 C_{w}^{s}=38.5+0.51 C_{w}^{s} \\
& \text { Liver } \\
& S_{L}=0.028 S_{0}+0.51 C_{W}^{s}=77+0.51 C_{w}^{s} \\
& \text { Brain } \\
& S_{x}=0.026 S_{0}+0.51 C_{w}^{s}=71.5+0.51 C_{W}^{s} \\
& \text { Blood } \\
& S_{B}=C_{W}^{s}+0.0035 S_{0}=C_{w}^{s}+9.5=C_{w}^{s}(1+ \\
& \left.0.0035 K_{o w}\right)
\end{aligned}
$$

If the chemical is aromatic $30 \mathrm{~mol} / \mathrm{m}^{3}$ is added to the blood solubility.

Each partition coefficient is then calculated as the ratio of the corresponding solubilities. These partition coefficients when plotted as in figs 1 to 4 show the expected good correlation with those observed by other workers. Much of the apparent correlation in these figures is attributable to the presence of a common variable on each axis. There are four common outliers: $1,1,1$ trichloroethane, trichloroethylene, chloroform, and 1-propanol. With the exception of trichloroethylene, these compounds were indicated in table 1 as having suspect octanol solubilities. These may be due to errors in the calculated water solubilities.

Figure 5 is a regression of correlated values of fat/ blood and kidney/blood partition coefficients. The line corresponding to the regression is essentially a plot of $\left(38.5+0.51 \mathrm{C}_{\mathrm{w}}^{\mathrm{s}}\right) /\left(9.5+\mathrm{C}_{\mathrm{w}}^{\mathrm{s}}\right)$ versus $2000 /\left(9.5+\mathrm{C}_{\mathrm{w}}^{\mathrm{s}}\right)$ (except for the aromatics) which is nearly linear, extending from a limit on the left side of partition

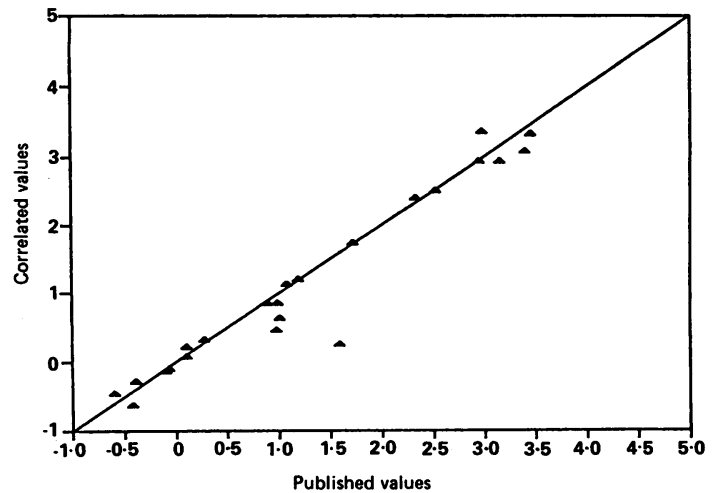

Fig 1 Comparison of published and correlated values of blood/air partition coefficients (logarithmic scale).

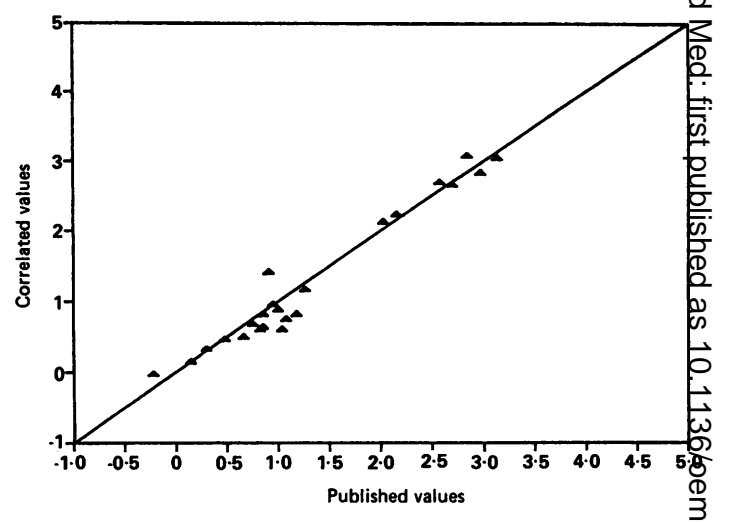

Fig 2 Comparison of published and correlated values of kidney/air partition coefficients (logarithmic scale).

coefficients of 0.51 (kidney/blood) and 0 (fat/blood for a chemical of infinite water solubility to a limit of $38.5 / 9.5$ or 4.0 (kidney/blood) and $2000 / 9.5$ or 210 (fat/blood) for a chemical of negligible watef solubility. The intermediate points lie approximate on a straight line. The exceptions are the three aromatics, benzene, toluene, and styrene, whoss solubilities in blood include a correction factor of $30 \mathrm{~mol} / \mathrm{m}^{3}$.

The advantage of this approach is that it shovs clearly the dominant determinants of partition coefficients. Usually it is water solubility or a a solubility - that is, vapour pressure. Furthermore, f \& a chemical that is similar in nature to this group it possible to estimate the partition coefficients from only a knowledge of vapour pressure and water solubility; no other partition coefficient is needed. The method may also help to elucidate the presence of unusually high solubilities or binding to protein of other material. Similar correlations could be developed for other groups of chemicals.

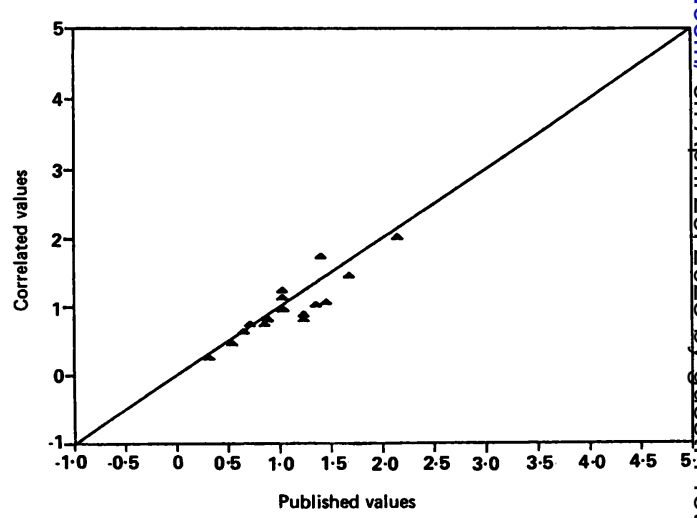

Fig 3 Comparison of published and correlated values of liver/air partition coefficients (logarithmic scale). 


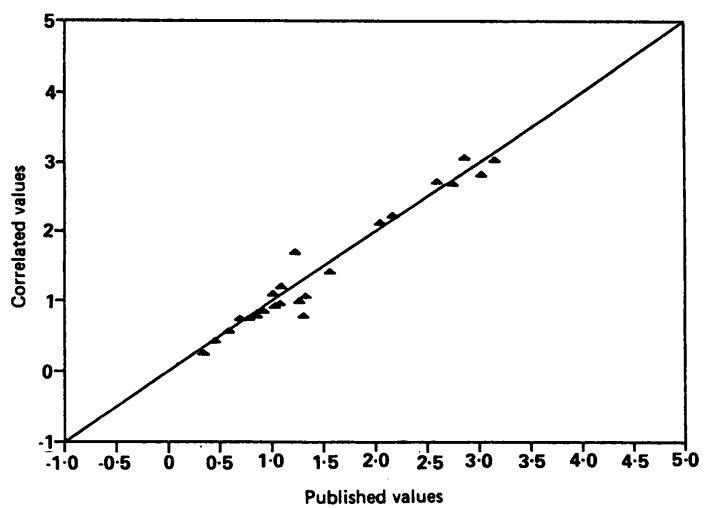

Fig 4 Comparison of published and correlated values of brain/air partition coefficients (logarithmic scale).

Improvements in the correlation could be made by developing more detailed expressions for blood and tissue solubilities taking into account the various solute-solvent interactions which apply. The solvatochronic parameter approach described by Abraham $e t$ al is particularly promising. ${ }^{15}$ For example, the use of a single solubility in fat is almost certainly a naive assumption and improvements in the correlation could be obtained by expressing this solubility as a function of molecular properties such as molar volume or dipole moment. There is no substitute for accurate, measured partition coefficients but these measurements are difficult to make and data are often lacking for uncommon systems. It is believed that the approach described here provides a simple method of estimating partition coefficients and checking the reasonableness and consistency of published values. It identifies more clearly the factors which underlie partition coefficient correlations.

\section{Application to calculations of equilibrium partitioning}

Having established the relative solubilities in these

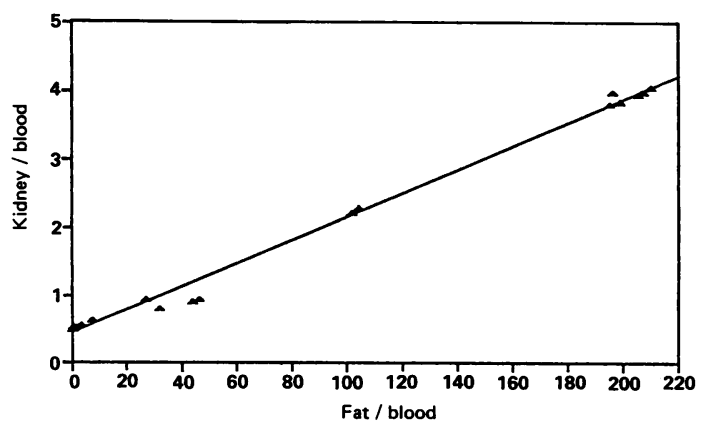

Fig 5 Regression of correlated values of fat/blood and kidney/blood partition coefficients. phases, it is possible to use them to calculate equilibrium distributions of these chemicals. At equilibrium, the fugacity of the chemical is equal in each phase, as is the ratio of fugacity to vapour pressure $f / P^{s}$. But $f / P^{s}$ is also the ratio of the concentration to the solubility in each phase and is the thermodynamic activity which may also be used as a criterion of equilibrium. If the concentration in one phase is known-for example, air-then the activity in that phase may be calculated as the ratio of concentration to solubility in air $\mathrm{C}_{\mathbf{A}}^{s}$ or $\mathrm{P}^{s} / \mathbf{R T}$. At equilibrium, all other phases will have identical activities, thus their concentrations may be deduced. Algebraically, this is equivalent to using partition coefficients.

Furthermore, if phase or tissue volumes are known the absolute and relative amounts of chemical in each phase may be deduced as shown in table 4 , which shows the equilibrium distribution of dichloromethane in someone exposed to a concentration of $100 \mathrm{ppm}$ (volume). Dichloromethane has a partial pressure of $10.1 \mathrm{~Pa}$ or an air concentration of $0.0039 \mathrm{~mol} / \mathrm{m}^{3}$ or $100 \mathrm{ppm}$ at $37^{\circ} \mathrm{C}$. Since the vapour pressure of dichloromethane is $91800 \mathrm{~Pa}$, this corresponds to an activity of 0.00011 . The concentration in each phase will then be 0.00011 times the solubility, and the amounts will be as shown in table 4. The calculated blood concentration agrees within a factor of three with the concentration of $1 \mathrm{mg} / \mathrm{l}$ reported by Anderson et al. ${ }^{17}$ The reported concentration is close to steady state but is not quite at steady state. The steady state concentration will be lower than the calculated equilibrium concentration because of metabolic conversions. The tissue concentrations thus adopt values controlled by the relative rates of metabolism and intake by inhalation.

A similar calculation for styrene at $80 \mathrm{ppm}$ gives an equilibrium blood concentration of $19 \mathrm{mg} / \mathrm{l}$ which is a factor of 19 greater than the observed value. This large factor is due to the rapid metabolism of styrene. An equilibrium model such as this must be used with caution because the concentrations represent maximum achievable values. When metabolism is rapid, considerably lower concentrations occur. As metabolic saturation is approached, the equilibrium model becomes more reliable.

The calculation may also be done using another concentration as a basis. For example, if the blood concentration is known the activity may be deduced and the other concentrations estimated.

Finally, if a total amount of chemical (body burden) is known then the activity may be deduced from that amount $\mathrm{M}$ mol, as

$$
\mathrm{M}=\Sigma \mathrm{C}_{\mathrm{i}} \mathrm{V}_{\mathrm{i}}=\Sigma \mathrm{AS}_{\mathrm{i}} \mathrm{V}_{\mathrm{i}}=A \Sigma \mathrm{S}_{\mathrm{i}} \mathrm{V}_{\mathrm{i}}
$$$$
\text { or } \quad A=M / \Sigma S_{i} V_{i} \text { then } C_{i}=A S_{i}
$$

where $S_{i}$ is the phase solubility $\left(\mathrm{mol} / \mathrm{m}^{3}\right)$ and $V_{i}$ the 
Table 4 Calculation of equilibrium distribution of dichloromethane (DCM) at 1 atm (101325 Pa) and $37^{\circ} \mathrm{C}$ and an inhalation exposure of $100 \mathrm{ppm}$ ( vol)

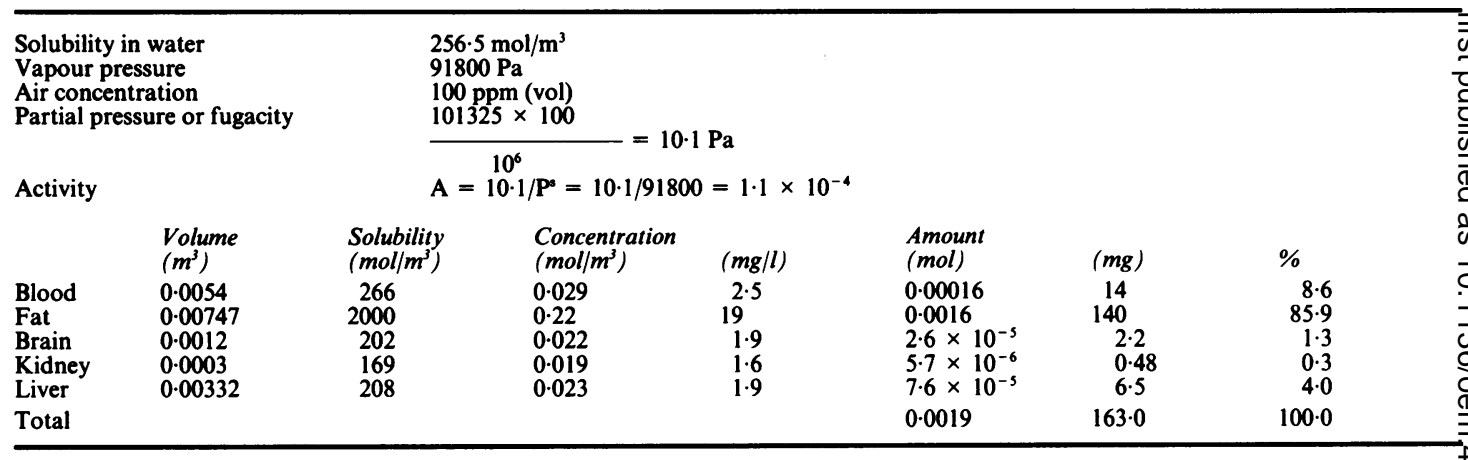

volume $\left(\mathrm{m}^{3}\right)$. This is useful in exploring the likely concentrations which will result from uptake of a given amount of chemical.

\section{Conclusions}

A novel method has been suggested for estimating blood/air and tissue/blood partition coefficients from the physical chemical properties of a chemical. The approach is firstly to estimate the chemical solubilities or pseudosolubilities in water and air. The mean solubilities in octanol, fat, and oil and then various tissues may be calculated. Various partition coefficients may then be estimated as ratios of the appropriate solubilities. This approach avoids statistical difficulties associated with correlating a quantity with itself, and it helps to elucidate the source of variation in, and magnitude of, partition coefficients. The application of the method to calculating concentrations and amounts of chemical in various physiological compartments has been illustrated.

We thank the Ontario Ministry of the Environment for financial support.

\section{References}

1 Fiserova-Bergerova V. Gases and their solubilities. In: Modelling of inhalation exposure to vapors: uptake, distribution and elimination. Vol 1. Boca Raton: CRC Press, 1983:3-28.

2 Fiserova-Bergerova V, Diaz ML. Determination and prediction of tissue-gas partition coefficients. Int Arch Occup Health 1986;58:75-87.

3 Perbellini L, Brugnone F, Caretta D, Maranelli G. Partition coefficient of some industrial aliphatic hydrocarbons (C5-C7 $)_{\text {U }}$ in blood and human tissues. $\mathrm{Br}$ J Ind Med 1985;42:162-7. N

4 Sato A, Nakajima T. Partition coefficients of some aromatic hydrocarbons and ketones in water, blood, and oil. Br J Inas Med 1979;36:231-4.

5 Prausnitz JM. Molecular thermodynamics of fluid phase equilibria Englewood Cliffs, NJ: Prentice Hall, 1969.

6 Reid RC, Prausnitz JM, Sherwood TK. The properties of gases and liquids, 3rd ed. New York: McGraw-Hill, 1977.

7 Hansch C, Leo AJ. Substituent constants for correlation analysis ing chemistry and biology. New York: Wiley and Sons, 1979.

8 Miller MM, Wasik SP, Huang GL, Shiu WY, Mackay D? Relationships between octanol-water partition coefficient ans aqueous solubility. Environmental Science and Technolog 1985;19:522-9.

9 Hala E, Wichterle I, Polak J, Boublik T. Vapour-liquid equilibriun data at normal pressures. New York: Pergamon Press, 1986.

10 Mackay D, Paterson S, Cheung B, Neely WB. Evaluating the environmental behaviour of chemicals with a level III fugacity model. Chemosphere 1985;14:335-74.

11 Mackay D, Shiu WY. A critical review of Henry's law constants for chemicals of environmental interest. Journal of Physical and Chemical Reference Data 1982;10:1175-99.

12 Lyman WJ, Reehl WF, Rosenblatt DH. Chemical propert estimation models. New York: McGraw-Hill, 1982.

13 Verschueren K. Handbook of environmental data on organiל chemicals. New York: Van Nostrand Reinhold, 1983.

14 Wilhoit RC, Zwolinski BJ. Handbook of vapor pressures and heat of vaporization of hydrocarbons and related hydrocarbons. Texa@ $A$ and $M$ University, Texas: Thermodynamics Research Center, 1971.

15 Abraham MH, Kamlet MJ, Taft RW, Doherty RM, Weathersby PK. Solubility properties in polymers and biological media. 2 The correlation and prediction of the solubilities of nonelect trolytes in biological tissues and fluids. Journal of Medicinat Chemistry 1986;28:865-70.

16 Ramsey JC, Andersen ME. A physiologically based description of the inhalation pharmacokinetics of styrene in rats and humans Toxicol Appl Pharmacol 1984;73:159-75.

17 Anderson ME, Clewel III HJ, Gargas L, Smith FA, Reitz RH Physiologically based pharmakokinetics and the risk assess ment process for methylene chloride. Toxicol Appl Pharmac\& 1987;87:185-205. 